\title{
Leaf miner incidence in coffee plants under different drip irrigation regimes and planting densities
}

\author{
Gleice Aparecida Assis(1), Franscinely Aparecida Assis(2), Myriane Stella Scalco(1), \\ Francisco José Toloza Parolin(2), Iraci Fidelis ${ }^{(1)}$, Jair Campos Moraes ${ }^{(2)}$ and Rubens José Guimarães ${ }^{(1)}$ \\ (1)Universidade Federal de Lavras (Ufla), Departamento de Agricultura, Caixa Postal 3037, CEP $37200-000$ Lavras, MG. \\ E-mail: gleice_ufla@hotmail.com, msscalco@dag.ufla.br, iracifi17@hotmail.com, rubensjg@dag.ufla.br (2)Ufla, Departamento de Entomologia. \\ E-mail: franscinelyagronomia@yahoo.com.br, fjtparolin4144@yahoo.com.br, jcmoraes@den.ufla.br
}

\begin{abstract}
The objective of this work was to evaluate the effect of different drip irrigation regimes and planting densities on the incidence of the leaf miner, Leucoptera coffeella, in arabica coffee plants for one year. The experiment was carried out in 2008, in a complete randomized block design, in a split-plot in time arrangement, with four replicates. The treatments consisted of four drip irrigation regimes - soil water balance, irrigations at 20 and $60 \mathrm{kPa}$ soil tensions, and a nonirrigated treatment -, which were distributed at three plant densities: $2,500,5,000$, and 10,000 plants per hectare. The evaluations were made on a monthly basis between January and December 2008. The highest pest occurrence period was from August to November, a season with low-air relative humidity preceded by a drought period. Irrigated coffee plants showed an incidence of intact mines 2.2 times lower than that of nonirrigated plants. Irrigation and increasing of plant density contribute to the reduction of coffee leaf miner occurrence.

Index terms: Coffea arabica, Leucoptera coffeella, irrigation, spacing, weather factors.

\section{Incidência de bicho-mineiro em cafeeiros sob diferentes regimes de irrigação por gotejamento e densidades de plantio}

Resumo - O objetivo deste trabalho foi avaliar o efeito de diferentes regimes de irrigação por gotejamento e densidades de plantio na incidência do bicho-mineiro, Leucoptera coffeella, em cafeeiro arábica, ao longo de um ano. O experimento foi realizado em 2008, em delineamento de blocos ao acaso, em parcelas subdivididas no tempo, com quatro repetições. Os tratamentos consistiram de quatro regimes de irrigação por gotejamento - balanço hídrico climatológico, irrigações com base nas tensões de 20 e $60 \mathrm{kPa}$, e uma testemunha não irrigada -, os quais foram distribuídos em três densidades de plantio: 2.500, 5.000 e 10.000 plantas por hectare. As avaliações foram realizadas mensalmente entre janeiro e dezembro de 2008. O maior período de ocorrência da praga foi registrado de agosto a novembro, época de baixa umidade relativa do ar antecedida por período de estiagem. Cafeeiros irrigados apresentaram incidência de minas intactas 2,2 vezes menor do que as plantas não irrigadas. A irrigação e o aumento da densidade de plantio contribuem para a redução da incidência do bicho-mineiro do cafeeiro.
\end{abstract}

Termos para indexação: Coffea arabica, Leucoptera coffeella, irrigação, espaçamento, fatores meteorológicos.

\section{Introduction}

The coffee business has a vital importance in several economies and plays a major role in three of the world's largest producers: Brazil, Vietnam and Colombia (Food and Agriculture Organization of the United Nations, 2011). Because of coffee's great social and economic culture value, procedures and new technologies, which may reduce losses and production costs, should be adopted (Cunha et al., 2011).

The coffee leaf miner, Leucoptera coffeella (Guérin-Méneville, 1842) (Lepidoptera: Lyonetiidae), is a pest of major economic importance, due to its several peak occurrences during the year, which have caused production losses from 34.3 to $41.5 \%$ (Reis \& Souza, 1996).

Injuries caused by the leaf miner lead to leaf area reduction by necrosis of the leaf surface and may result in leaf fall. Injuries are intensified when mines are made near the leaf petiole, which reduces floral sprout formation (Gallo et al., 2002).

The leaf miner population dynamics is related to the occurrence of natural enemies, host plant characteristics, intra- and interspecific competition, and to weather conditions, such as winds, chilling, 
rain, relative humidity and temperature (Lomelí-Flores et al., 2010).

Rainfall is negatively related to coffee leaf miner development since it limits the flying and mating of insects, which contributes to reduce the viability of young instars (Zalucki et al., 2002; Bacca et al., 2006). Relative humidity also has a negative influence on the occurrence of leaf miner; however, temperature favors leaf miner populations (Nestel et al., 1994) by increasing the reproduction rate and larval development. Coffee plants located in high-wind-speed areas or at low heights with low-relative humidity show favorable conditions for L. coffeella action (Matiello et al., 2010).

In addition, plant spacing should be taken into account for the establishment of coffee plantations, since large spacings among plants favors leaf miner occurrence (Tuelher et al., 2003). The expansion of the Brazilian coffee business to areas that are not favorable for the establishment of the crop, with insufficient raining conditions or bad temporal distribution, make irrigation a necessary practice to achieve high productivity (Silva et al., 2008). The characteristics of irrigated plants differ from those of the nonirrigated ones as to physiology and other technical aspects, because irrigation creates a different microclimate. Therefore, plantation management should also be taken into account (Meireles et al., 2001).

Climate changes may alter the current scenario of pests in Brazilian agriculture. The infestation of $L$. coffeella will increase on coffee crops under future scenarios when compared with the climatological normal from 1961-1990 (Ghini et al., 2008).

This objective of this work was to evaluate the effect of different irrigation regimes and planting densities on the incidence of the coffee leaf miner in arabica coffee plants for one year.

\section{Materials and Methods}

This experiment was carried out at the Universidade Federal de Lavras, Lavras, MG, Brazil $\left(21^{\circ} 14\right.$ 'S and $45^{\circ} 00^{\prime} \mathrm{W}$, at $910-\mathrm{m}$ altitude), from January 2008 to December 2008. The climate of the region is Cwa type, according to Köppen classsification (Dantas et al., 2007). Annual means for rainfall, relative air humidity and temperature are, respectively, $1,529.7 \mathrm{~mm}, 76.2 \%$ and $19.4^{\circ} \mathrm{C}$.
The soil of the experimental area is classified as Latossolo Vermelho distrófico (Rhodic Hapludox) and was analyzed for physical and moisture characteristics at the soil depths of: $0-0.20,0.20-0.40$ and $0.40-0.60 \mathrm{~m}$. Soil physical analysis showed: $27 \%$ sand, $20 \%$ silt, $53 \%$ clay, $44.7 \%$ microporosity, $7.5 \%$ macroporosity, and $1.2 \mathrm{~g} \mathrm{~cm}^{-3}$ density for the $0-0.20-\mathrm{cm}$ soil layer. For the other layers, the soil analysis showed: $23 \%$ sand, $9 \%$ silt, $68 \%$ clay, $17.5 \%$ and $31.3 \%$ macroporosity, 39.1 and $33.6 \%$ microporosity, and 1.1 and $0.9 \mathrm{~g} \mathrm{~cm}^{-3}$ density, respectively, for the $0.20-0.40 \mathrm{~m}$ and $0.40-0.60-\mathrm{m}$ soil depths. For the same three soil layers, the soil water retention curve was adjusted to the Van Genuchten (1980) model, by which volumetric soil water content $(\theta)$ is related to matric potential $(\Psi \mathrm{m})$ values expressed in meters (Table 1).

Analysis of the water used in the drip irrigation system showed $6.5 \mathrm{pH}$ and $0.11 \mathrm{dS} \mathrm{m}^{-1}$ electrical conductivity, with concentrations of $\mathrm{HCO}_{3}, \mathrm{Ca}$, and $\mathrm{Mg}$ equal to 4.3, 14.4, and $3.336 \mathrm{meq} \mathrm{L}^{-1}$, respectively. Salinity was considered low, indicating that this water could be used for irrigation in most crops and soils, with little probability of causing salinity.

Planting of C. arabica 'Rubi MG-1192' seedlings was done in January 2001. Liming and fertilization were carried out according to the recommendations for the use of correctives and fertilizers in state of Minas Gerais, Brazil (Guimarães et al., 1999) for crops requiring soil and leaf analyses. The amounts of applied fertilizer were increased by $30 \%$, as recommended by Santinato \& Fernandes (2002) for irrigated coffee plantations. Monoammonium phosphate (MAP) was spread under the canopy area of the plants. A mixture of potassium nitrate $\left(\mathrm{KNO}_{3}\right)$ and urea was applied as fertigation. The experimental area was kept weed-free by an association of mechanical and chemical methods, according to the

Table 1. Curve equations of soil water retention for $0.0-0.2$, $0.2-0.4$, and $0.4-0.6-\mathrm{m}$ soil depths.

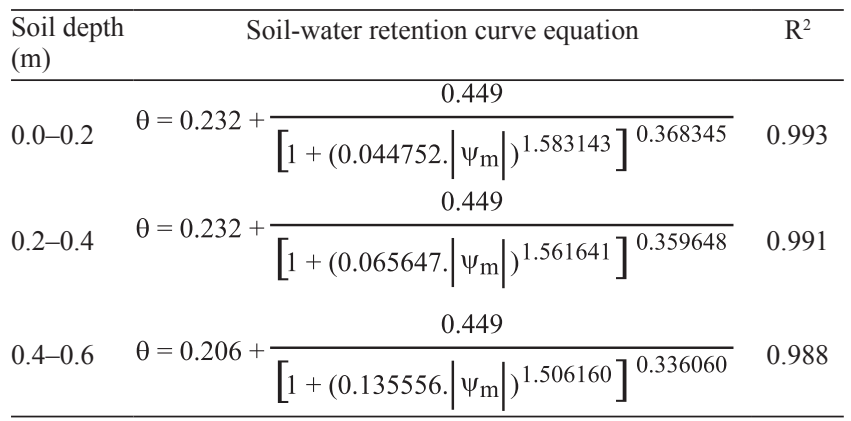


infesting species. During the experiment, spraying for the control of L. coffeella was not carried out.

A complete randomized block design, in a split-plot in time arrangement, with 12 treatments was used. Four replicates of four irrigation regimes were randomly distributed along each one of the five main blocks. Each main block was set up in a different planting density: 2,500 plants per hectare, with $4.0 \mathrm{~m}$ between rows and $1.0 \mathrm{~m}$ within rows; 5,000 plants per hectare, with $2.0 \mathrm{~m}$ between rows and $1.0 \mathrm{~m}$ within rows; and 10,000 plants per hectare, with $2.0 \mathrm{~m}$ between rows and $0.5 \mathrm{~m}$ within rows. These planting densities were subjected to four irrigation regimes: every Monday, Wednesday, and Friday, with amounts of applied water determined by meteorological water balance; when soil water tension reached values close to $20 \mathrm{kPa}$ at $0.25-\mathrm{m}$ soil depth; when soil water tension reached values close to $60 \mathrm{kPa}$ at $0.25-\mathrm{m}$ soil depth; and a control without irrigation.

Each block was composed by an equal total number of coffee plants uniformly distributed along an equal number of planting rows. Except for the first and the last planting rows of each block, which were used as nonirrigated border rows, there were four experimental parcels (split plots) along the internal planting rows of each block. Each one of these parcels was composed by ten consecutive plants disposed along a continuous plant row segment. The first and the last plant of each segment were not considered for measurement purposes.

On all blocks, four different lateral lines were laid out along each planting row of irrigated coffee. Two laterals were laid out on each side of the rows. Along the length of each experimental parcel, which was composed by a continuous planting row segment with ten coffee plants, dripper emitters were installed on only one of the four lateral lines: the one managed according to the parcel's irrigation regime. On these lateral line segments, online pressure-compensated drippers, with a discharge of $3.78 \mathrm{~L}$ per hour, were uniformly installed and spaced by $0.4 \mathrm{~m}$. Within each block, each group of lateral lines, subjected to the same irrigation regime, was independently managed.

In parcels receiving irrigation based on the soil water potential value $(20$ or $60 \mathrm{kPa})$, soil moisture content inside the wetted soil volume was indirectly monitored using tensiometers and an electronic tensimeter with a hypodermic needle. Tensiometers were installed along the central part of the wetted soil volume below the line sources, as determined by the position of the irrigation lateral lines that were laid out on the same alignment determined by planting rows, at $0.10,0.25,0.40$, and $0.60-\mathrm{m}$ soil depths. Irrigation was applied whenever the soil water tension at $0.25 \mathrm{~m}$ reached approximately the treatment's pre-defined value (20 or $60 \mathrm{kPa})$. Applied irrigation water amounts were computed based on the water volume required for the soil moisture content of the entire parcel to reach the field capacity value. In these treatments, the wetted soil volume was computed as a $0.6-\mathrm{m}$ wide rectangular block, with same-length parcels and a depth equal to that of the coffee tree effective root. This maximum value was fixed according to local experimental observations, as reported by Alves (2008).

On plots receiving irrigation every Monday, Wednesday, and Friday, the applied irrigation water amounts were computed by soil water balance (SWB) in which daily values of coffee tree evapotranspiration were estimated by the product of daily reference evapotranspiration and crop coefficient values. Daily reference evapotranspiration values were computed according to the Penman-Monteith method. Meteorological data required for reference evapotranspiration computation (daily values of mean temperatures $\left({ }^{\circ} \mathrm{C}\right)$, maximum and minimum relative humidity $(\%)$, solar radiation $\left(\mathrm{W} \mathrm{m}^{-2}\right)$, and wind speed $\left(\mathrm{m} \mathrm{s}^{-1}\right)$ at $2 \mathrm{~m}$ of height) were monitored by an automatic $\mu$ Metos weather station (Pessl Instruments $\mathrm{GmbH}$, Weiz, Austria) installed in the experimental area. Daily rainfall $(\mathrm{mm})$ values were also monitored by the same $\mu$ Metos meteorological station. Crop coefficient (Kc) values were selected according to Santinato et al. (1996).

The evaluations for coffee leaf miner population were done once a month from January to December 2008. Leaf miner presence or absence was assessed on plants by a nondestructive method, which consisted of the random selection of a branch in the middle third of the plant. The presence or absence of leaf miners was measured in the $3^{\text {rd }}$ or $4^{\text {th }}$ leaf pair of the branch. The mean percentage data of mined leaves, collected in each evaluation, were transformed by the arc sine $(\mathrm{x} / 100)^{0.5}$. Analyses of variance were done with the Sisvar software (Ferreira, 2008), and means were compared by the Scott-Knott test, at 5\% probability. The mine percentages were analyzed according to a split-plot in time arrangement, considering the months of the split plot in time. 


\section{Results and Discussion}

Major irrigation needs occurred when soil water tension reached values near $20 \mathrm{kPa}$ (SWT $20 \mathrm{kPa}$ ) (Table 2). However, in the soil water balance treatment (SWB), the irrigations were made in fixed times and, consequently, were more frequent in relation to the other adopted regimes. The minor water depth applied in this regime, in comparison to the SWT $20 \mathrm{kPa}$ could be explained by the coffee pruning on August 2007, which resulted in a minor culture coefficient $(\mathrm{Kc})$, and in a reduction of the evapotranspiration estimative and of the water depth applied on plants. The range of the $\mathrm{Kc}$ is dependent on leaf area, plant density per area and on the presence of weeds (Villa Nova et al., 2002). Therefore, this coefficient is a great physical and biological indicator, since it is associated to plant architecture and transpiration.

As for the density of plants per area, a greater water need (major water depth applied values) was observed in higher plant densities (10,000 plants per hectare) and a minor water need in lower plant densities (2,500 plants per hectare), which confirms the relation between higher plant populations and greater water consumption per unit area, as described by Kiara \& Stolzi (1986).

The interaction between plant densities and times of evaluation were significant $(\mathrm{p} \leq 0.05)$ for mine percentage. Major pest occurrences were registered from August to November (Figure 1). Injuries caused by L. coffeella increased after the dry season (May, June, and July), and the pest population decreased in the rainy season (Figure 2). These results are similar to the ones obtained by Oliveira et al. (2001), who observed an increase of $L$. coffeella infestation in the dry period (June-October) in 'Mundo Novo' coffee plants.

In months of lower-relative humidity (Figure 2), the highest levels of pest infestation were registered, indicating that this weather variable favors insect

Table 2. Irrigation depths $(\mathrm{mm})$ in 2008 , at different combinations of planting densities and irrigation treatments.

\begin{tabular}{lccc}
\hline Planting density & \multicolumn{3}{c}{ Irrigation treatment $^{(1)}$} \\
\cline { 2 - 4 } (plants per hectare) & SWB & SWT $(20 \mathrm{kPa})$ & SWT $(60 \mathrm{kPa})$ \\
\hline 2,500 & 230.7 & 235.1 & 170.9 \\
5,000 & 280.8 & 454.5 & 201.5 \\
10,000 & 405.5 & 561.1 & 254.7 \\
\hline
\end{tabular}

${ }^{(1)} \mathrm{SWB}$, soil water balance; SWT, soil water tension. population. In these months, the registered mean temperature was $19.9^{\circ} \mathrm{C}$, which may have affected the behavior, life cycle and reproductive rate of the insect (Tuelher et al., 2003).

One possible explanation for the reduction of the leaf miner population after November, in addition to the change in weather conditions, is that, during these months, rainfall is more frequent and abundant. This is favorable to coffee vegetative growth due to the consecutive emission of new leaves (Blanco et al., 2003; Conceição et al., 2005). The first new leaf pairs sprouted by the plant are usually not used by L. coffeella females for oviposition and, when they

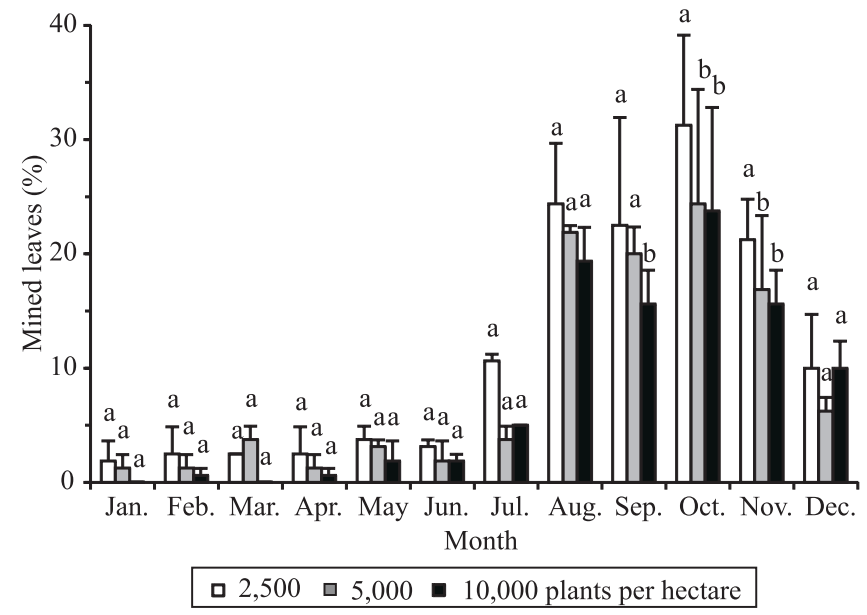

Figure 1. Percentage of mined leaves in coffee at different plant densities during 2008. $\mathrm{CV}=47.19 \%$.

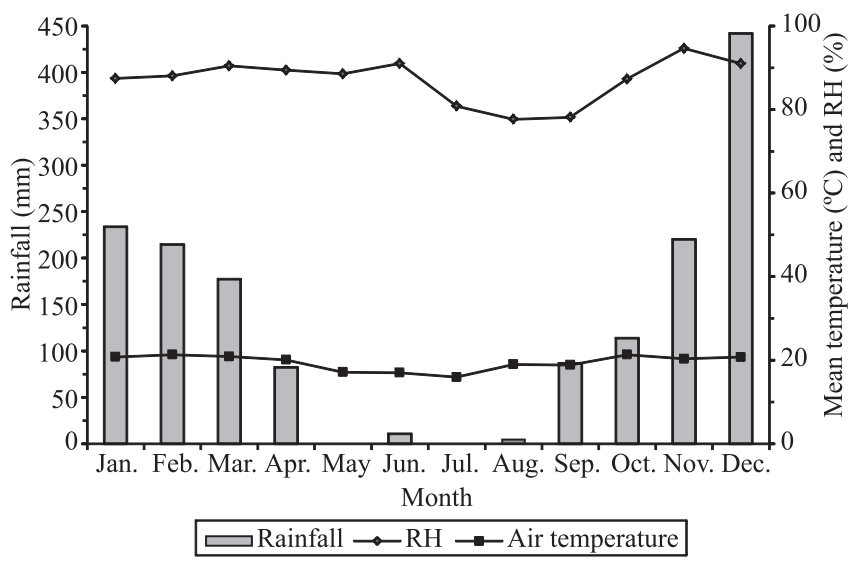

Figure 2. Rainfall, mean air temperature and air relative humidity (RH), from January to December 2008, in Lavras, MG, Brazil. 
are used, there is an increase in larval mortality and a decrease in egg hatching, which reduces adult fertility (Guerreiro Filho, 2006).

Plant density only had significant effects in the months of increased pest occurrence. There were more mined leaves in low-plant densities, indicating that the increase of plant density is an important practice because it creates a shady wet microclimate, which has a negative effect on insect population. This confirms the data reported by Reis \& Souza (1996) and Pereira et al. (2007).

In September, the percentages of intact mine on plant densities of 2,500 and 5,000 plants per hectare were $36.2 \%$ greater than those of 10,000 plants per hectare and, in October and November, the percentages were 29.7 and $30.5 \%$ greater on 2,500 plants per hectare than on the other two plant densities.

In addition, there was a significant effect $(p \leq 0.05)$ of the interactions among months and irrigation regimes as for percentage of mined leaves (Figure 3). An effect of irrigation was observed only in October, which is considered the month of highest insect occurrence. The mean percentage of mined leaves, observed on irrigated plants (regardless of the irrigation regime), was $20.3 \%$, which is an occurrence 2.2 times lower than that observed for nonirrigated plant plots.

According to Fernandes et al. (2009), plants under drought show biochemical changes in primary and secondary metabolite levels, which are favorable to the insect's performance because of the increase in nitrogen levels and the reduction in the plant's defense chemicals.

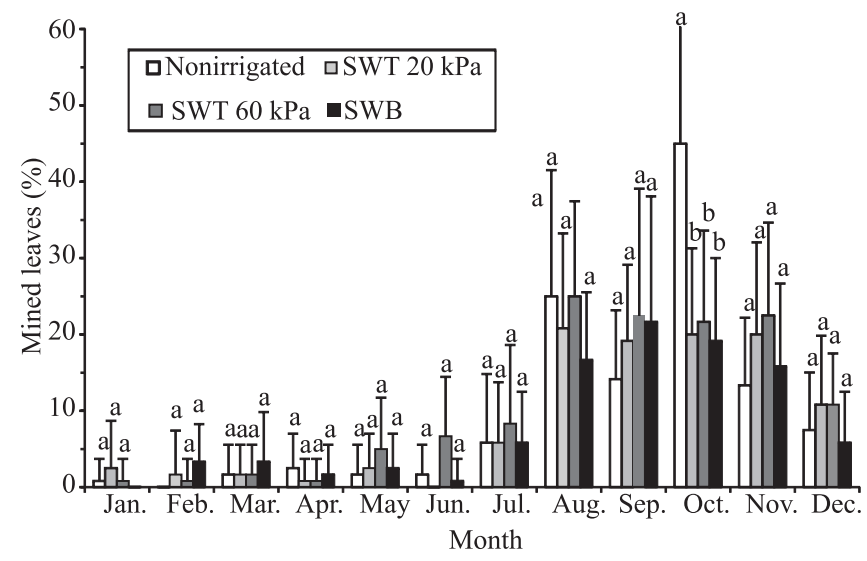

Figure 3. Percentage of mined leaves in coffee under different drip irrigation regimes during 2008. SWT, soil water tension; SWB, soil water balance. $\mathrm{CV}=47.19 \%$
The direct reposition of water in the soil, with little effect on microclimatic conditions, may adversely affect the leaf miner (Meireles et al., 2001), due to possible nutritional changes and to the production of secondary compounds in plants. In addition, Custódio et al. (2009) also observed a reduction in the incidence of leaf miner, explained by the increase of relative humidity and leaf wetness, obtained by different microclimates provided through an irrigation system with a central pivot. Therefore, even irrigation and increases on plant densities may increment productivity and contribute to coffee leaf miner management.

\section{Conclusions}

1. In the evaluated region, the highest coffee leaf miner occurrence is between August and November, the period with the lowest-relative humidity, preceded by a drought period.

2. Irrigation reduces more than twice the incidence of leaf miner and is a promising technique in the integrated management of this pest.

3 . The increase on plant density reduces the crop susceptibility to the attack by coffee leaf miner.

\section{Acknowledgements}

To Fundação de Amparo à Pesquisa do Estado de Minas Gerais, to Conselho Nacional de Desenvolvimento Científico e Tecnológico, and to Consórcio Pesquisa Café, for financial support.

\section{References}

ALVES, J.D. Morfologia do cafeeiro. In: CARVALHO, C.H.S. de. Cultivares de café: origem, características e recomendações. Brasília: Embrapa Café, 2008. p.35-58.

BACCA, T.; LIMA, E.R.; PICANÇO, M.C.; GUEDES, R.N.C.; VIANA, J.H.M. Optimum spacing of pheromone traps for monitoring the coffee leaf miner Leucoptera coffeella. Entomologia Experimentalis et Applicata, v.119, p.39-45, 2006.

BLANCO, M.; HAGGAR, J.; MORAGA, P.; MADRIZ, J. del C.; PAVÓN, G. Morfología del café (Coffea arabica L.), en lotes comerciales. Nicaragua. Agronomía Mesoamericana, v.14, p.97-103, 2003.

CONCEIÇÃO, C.H.C.; GUERREIRO-FILHO, O.; GONÇALVES, W. Flutuação populacional do bicho-mineiro em cultivares de café arábica resistentes à ferrugem. Bragantia, v.64, p.625-631, 2005.

CUNHA, J.P.A.R. da; GITIRANA NETO, J.; BUENO, M.R. Evaluation of a device for the application of pesticides on 
mechanized coffee crops (Coffea arabica L.). Interciencia, v.36, p.312-316, 2011.

CUSTÓDIO, A.A. de P.; MORAES, J.C.; CUSTÓDIO, A.A. de P.; LIMA, L.A.; FARIA, M.A. de; GOMES, N.M. Incidência do bicho-mineiro do cafeeiro em lavoura irrigada sob pivô central. Coffee Science, v.4, p.16-26, 2009.

DANTAS, A.A.A.; CARVALHO, L.G. de; FERREIRA, E. Classificação e tendências climáticas em Lavras, MG. Ciência e Agrotecnologia, v.31, p.1862-1866, 2007.

FOOD AND AGRICULTURE ORGANIZATION OF THE UNITED NATIONS. FAOSTAT: food and agricultural commodities production. Available at: <http://faostat.fao.org/ site/339/default.aspx>. Accessed on: 5 May 2011.

FERNANDES, F.L.; MANTOVANI, E.C.; BONFIM NETO, H.; NUNES, V. de V. Efeitos de variáveis ambientais, irrigação e vespas predadoras sobre Leucoptera coffeella (Guérin-Méneville) (Lepidoptera: Lyonetiidae) no cafeeiro. Neotropical Entomology, v.38, p.410-417, 2009.

FERREIRA, D.F. SISVAR: um programa para análises e ensino de estatística. Revista Symposium, v.6, p.36-41, 2008.

GALLO, D.; NAKANO, O.; SILVEIRA NETO, S.; CARVALHO, R.P.L.; BATISTA, G.C. de; BERTI FILHO, E.; PARRA, J.R.P.; ZUCCHI, R.A.; ALVES, S.B.; VENDRAMIM, J.D.; MARCHINI, L.C.; LOPES, J.R.S.; OMOTO, C. Entomologia Agrícola. Piracicaba: FEALQ, 2002. 920p.

GHINI, R.; HAMADA, E.; PEDRO JÚNIOR, M.J.; MARENGO, J.A.; GONÇALVES, R.R.V. Risk analysis of climate change on coffee nematodes and leaf miner in Brazil. Pesquisa Agropecuária Brasileira, v.43, p.187-194, 2008.

GUERREIRO FILHO, O. Coffee leaf miner resistance. Brazilian Journal of Plant Physiology, v.18, p.109-117, 2006.

GUIMARÃES, P.T.G.; GARCIA, A.W.R.; ALVAREZ V., V.H.; PREZOTTI, L.C.; VIANA, A.S.; MIGUEL, A.E.; MALAVOLTA, E.; CORREA, J.B.; LOPES, A.S.; NOGUEIRA, F.D.; MONTEIRO, A.V.C. Cafeeiro. In: RIBEIRO, A.C.; GUIMARAES, P.T.G.; ALVAREZ V., V.H. (Ed.). Recomendações para o uso de corretivos e fertilizantes em Minas Gerais: 5a aproximação. Viçosa: Comissão de Fertilidade do Solo do Estado de Minas Gerais, 1999. p.289-302.

KIARA, J.M.; STOLZI, L.H. The effects of tree density and irrigation on coffee growth and production in Kenya. Applied Agricultural Research, v.1, p.26-31, 1986.

LOMELÍ-FLORES, J.R.; BARRERA, J.F.; BERNAL, J.S. Impacts of weather, shade cover and elevation on coffee leafminer Leucoptera coffeella (Lepidoptera: Lyonetiidae) population dynamics and natural enemies. Crop Protection, v.29, p.1039-1048, 2010.

MATIELLO, J.B.; SANTINATO, R.; GARCIA, A.W.R.; ALMEIDA, S.R.; FERNANDES, D.R. Cultura de café no
Brasil: manual de recomendações. Rio de Janeiro: Ministério da Agricultura, Pecuária e Abastecimento; Varginha: Fundação Procafé, 2010. 542p.

MEIRELES, D.F. de; CARVALHO, J. de A.; MORAES, J.C. Avaliação da infestação do bicho-mineiro e do crescimento do cafeeiro submetido a diferentes níveis de déficit hídrico. Ciência e Agrotecnologia, v.25, p.371-374, 2001.

NESTEL, D.; DICKSCHEN, F.; ALTIERE, M.A. Seasonal and spatial population loads of a tropical insect: the case of the coffee leaf-miner in Mexico. Ecological Entomology, v.19, p.159-167, 1994.

OLIVEIRA, M.A.S.; SAMPAIO, J.B.R.; GOMES, A.C. Dinâmica populacional do bicho-mineiro (Perileucoptera coffeella) em cafeeiro no Distrito Federal. Planaltina: Embrapa Cerrados, 2001. 19p. (Embrapa Cerrados. Boletim de pesquisa e desenvolvimento).

PEREIRA, S.P.; GUIMARÃES, R.J.; BARTHOLO, G.F.; GUIMARÃES, P.T.G.; ALVES, J.D. Crescimento vegetativo e produção de cafeeiros (Coffea arabica L.) recepados em duas épocas, conduzidos em espaçamentos crescentes. Ciência e Agrotecnologia, v.31, p.643-649, 2007.

REIS, P.R.; SOUZA, J.C. Manejo integrado do bicho-mineiro Perileucoptera coffeella (Guérin-Méneville, 1842) (Lepidoptera: Lyonetiidae), e seu reflexo na produção de café. Anais da Sociedade Entomológica do Brasil, v.25, p.77-82, 1996.

SANTINATO, R.; FERNANDES, A.L.T. Cultivo do cafeeiro irrigado em plantio circular sob pivô central. Belo Horizonte: Editora O Lutador, 2002. 250p.

SANTINATO, R.; FERNANDES, A.L.T.; FERNANDES, D.R. Irrigação na cultura do café. Campinas: Arbore, 1996. 145p.

SILVA, C.A. da; TEODORO, R.E.F.; MELO, B. de. Produtividade e rendimento do cafeeiro submetido a lâminas de irrigação. Pesquisa Agropecuária Brasileira, v.43, p.387-394, 2008.

TUELHER, E.S.; OLIVEIRA, E.E.; GUEDES, R.N.C.; MAGALHÃES, L.C. Ocorrência de bicho-mineiro do cafeeiro (Leucoptera coffeella) influenciada pelo período estacional e pela altitude. Acta Scientiarum. Agronomy, v.25, p.119-124, 2003.

VAN GENUCHTEN, M.T. A closed form equation for predicting the hydraulic conductivity of unsatured soils. Soils Science Society of America Journal, v.44, p.892-898, 1980.

VILLA NOVA, N.A.; FAVARIN, J.L.; ANGELOCCI, L.R.; DOURADO NETO, D. Estimativa do coeficiente de cultura do cafeeiro em função de variáveis climatológicas e fitotécnicas. Bragantia, v.61, p.81-88, 2002.

ZALUCKI, M.P.; CLARKE, A.R.; MALCOLM, S.B. Ecology and behavior of first instar larval Lepidoptera. Annual Review of Entomology, v.47, p.361-393, 2002.

Received on June 17, 2011 and accepted on January 24, 2012 